\title{
COMPARISON OF SAFETY INTRAABDOMINAL ANTIADHESIVE AGENT BASE ON HEPATETIC STEATOSIS IN WISTAR RAT
}

\section{Miftahurrahmah, Budi Justicia, Willy Hardy Marpaung}

Fakultas Kedokteran dan Ilmu Kesehatan Universitas Jambi, Indonesia

Email: miftahurrahman_fkik@Unja.ac.id,boedortho@yahoo.com,

willyhmdr@gmail.com

\begin{abstract}
Abstrak
Pembentukan adhesi peritoneal pasca operasi setelah operasi adalah hasil dari laparotomi. Madu memiliki obat sejarah panjang sebagai agen penyembuhan antiinflamasi, anti-bakteri dan luka. Mayoritas masyarakat menganggap obat herbal memiliki efek samping rendah tujuan penelitian ini untuk menyelidiki Perbandingan hepar mikroskopis pada wistar setelah antiadhesif intraabdominal. Dua puluh lima tikus wistar jantan dibagi menjadi lima kelompok. Kontrol kelompok positif sebagai kelompok A, 0,9\% natrium klorida sebagai kelompok B, 0,27 ml / 200 gram dosis madu sebagai Kelompok C dan dosis 0,54 ml / 200 gram madu sebagai kelompok D. kontrol negatif sebagai Kelompok E. hepar mikroskopis seperti nekrosis, inflamasi dan perdarahan. Data akan dianalisis dengan metode statistik. Steatosis rata-rata pada grup A $(3,4)$, B $(3,2)$, C $(3,2), D$ $(3,4)$ dan $E(3,4)$., Steatosise perbandingan di grup A vs E tidak signifikan (p: 0,841) B Vs E (p: 0,841) grup C vs E (hal: 0,841) dan D Vs E (hal: 0,69). Madu Jambi sebagai agen antiadhesif aman karena hepar mikroskopis tidak mengalami kerusakan yang signifikan.
\end{abstract}

Kata Kunci: rightsizing; emosi negatif; perampingan organisasi

\section{Abstract}

Postoperative peritoneal adhesion formation after surgery is result of laparotomy. Honey has a long history medicine as anti-inflammatory, anti-bacterial and wound healing agent. Majority of the public considered herbal medicine as having low side effects the purpose of this study to investigate the Comparison of microscopic hepar in wistar after intraabdominal antiadhesive. Twenty five male wistar rats divide into five group. Control positive group as group A, $0.9 \%$ sodium chloride as group B, $0.27 \mathrm{ml} / 200$ gram dose of honey as Group C and $0.54 \mathrm{ml} 200 \mathrm{gram}$ dose of honey as group D. control negative as Group E. microscopic hepar such as necrosis, inflammatory and haemorage. The data will be analysed with statistic method. Mean steatosis at group A (3.4), B(3.2), C(3.2), D(3.4) and E (3.4)., Comparison steatosise in group $A$ vs $E$ was no significant (p: 0.841) B Vs E (p: 0.841) group $C$ vs $E$ (p: 0.841) and D Vs E (p: 0.69). Jambi's Honey as antiadhesive agent is safe because microscopic hepar was not significant damage.

Keywords: steatosis, hepar, Jambi's honey

$\begin{array}{ll}\text { How to cite: } & \text { Miftahurrahmah, Budi Justicia \& Willy Hardy marpaung (2022) Comparison of Safety Intraabdominal } \\ & \text { Antiadhesive Agent Base on Hepatetic Steatosis in Wistar RAT. Syntax Literate: Jurnal Ilmiah } \\ & \text { Indonesia, 7(1). http://dx.doi.org/10.36418/ Syntax-Literate.v7i1.6056 } \\ \text { E-ISSN: } & 2548-1398 \\ \text { Published by: } & \text { Ridwan Institute }\end{array}$

Published by: $\quad$ Ridwan Institute 
Received: 2021-12-20; Accepted: 2022-01-05; Published: 2022-01-15

\section{Pendahuluan}

Adhesi peritoneum merupakan konsekuensi yang dapat terjadi setelah dilakukan laparotomi (Giusto et al., 2016). Insiden adhesi sekitar 67 dan 93\%, hal ini merupakan sumber utama obstruksi pada usus halus, pembentukan fistula nyeri kronik pada pelvis, infertilitas sekunder pada perempuan, serta kesulitan pada saat reoperasi sehingga meningkatkan morbiditas dan mortalitas (Emre et al., 2009).

Proses adhesi merupakan suatu proses yang komplek meliputi seluler, biokemikal dan faktor immunologi (Giusto et al., 2016); (Negahi et al., 2019). Keseimbangan antara proses pembentukan fibrin dan fibrinolysis merupakan hal penting dalam proses tersebut. Pencegahan terjadinya adhesi intraabdominal pascalaparotomi berupa teknik operasi dan pemberian zat antiadhesif intraabdominal (Coccolini et al., 2013).

Agen non farmakologi yang dianggap memiliki riwayat sebagai anti inflamasi, antibakteri dan antioksidan seperti madu (Saber, Shekidef, \& Saber, 2015) (Vallianou, Gounari, Skourtis, Panagos, \& Kazazis, 2014). Madu Jambi memberikan efek anti adhesive terbaik pada luka bersih tidak terkontaminasi secara makroskopik berdasarkan derajat adhesi dan skor peritoneal adhesion indeks (Marpaung, Purwakhanti, Ayudya, \& Reza, 2021). Namun keamanan madu jambi perlu dilakukan penelitian lebih lanjut. Oleh sebab itu tujuan penelitian ini mengidentifikasi perbandingan gambaran mikroskopik hepar tikus wistar setelah pemberian madu intra abdominal.

\section{Metode Penelitian}

Penelitian ini merupakan penelitian hewan coba yang dilakukan di Laboratorium Biomedik Fakultas kedokteran Universitas Jambi. Adapun hewan coba yang digunakan berupa tikus putih galur wistar berjenis kelamin dengan berat badan 200 gram. Adapun zat anti adhesive yang digunakan berupa madu, dan normal saline. Madu yang digunakan merupakan madu yang diambil dari peternakan madu di provinsi Jambi. Madu tersebut di simpan terlebih dahulu didalam kulkas pada suhu 0 derajat celcius.

Kemudian tikus tersebut dilakukan laparotomy dan dikelompokkan menjadi lima kelompok yaitu Kelompok yang dilakukan laparotomy dan dilakukan abrasi peritoneum tapi tidak diberikan antiadhesif sebagai kelompok A, kelompok yang diberikan $\mathrm{NaCl}$ $0.9 \%$ intraperitoneum sebagai pencucian rongga abdomen sebagai kelompok B, kelompok pemberian madu dengan dosis $0.27 \mathrm{ml} / 200$ gram atau dosis minimal intra abdomen sebagai kelompok C, kelompok diberikan madu dengan dosis $0.54 \mathrm{ml} / 200$ gram atau madu maksimal intra abdomen sebagai kelompok D dan kelompok yang tidak dilakukan tindakan operatif sebagai kelompok E. lalu dilakukan pengambilan hepar pada hari ke 10. Penilaian derajat inflamasi, haemorhage dan nekrosis secara mikroskopis menggunakan skor 0,12 dan 3 seperti pada tabel berikut (Arsad, Esa, \& Hamzah, 2014) . 


\section{Tabel 1}

Penilaian Secara Semi Kualitatif

\begin{tabular}{ll}
\hline Skor & Deskripsi skor \\
\hline $\mathbf{0}$ & Tidak ada \\
\hline $\mathbf{1}$ & Ditemukan derajat ringan $\leq 30 \%$, \\
\hline $\mathbf{2}$ & Ditemukan derajat sedang $31-50 \%$. \\
\hline $\mathbf{3}$ & Ditemukan derajat berat $>50 \%$ \\
\hline
\end{tabular}

\section{Hasil Dan Pembahasan}

Pada Kelompok Abrasi Peritoneum, Untuk tikus yang tidak di temukan Steatosis/Vacuolisation sebanyak 0 atau sebesar $0.0 \%$, Derajat ringan sebanyak 1 atau sebesar $20.0 \%$, Derajat sedang sebanyak 0 atau sebesar $0.0 \%$ dan Derajat berat sebanyak 4 atau sebesar $80.0 \%$.

Pada Kelompok tikus yang diberikan $\mathrm{NaCl} 3 \mathrm{ml}$, Untuk tikus yang tidak di temukan Steatosis/Vacuolisation sebanyak 1 atau sebesar 20.0\%, Derajat ringan sebanyak 0 atau sebesar $0.0 \%$, Derajat sedang sebanyak 0 atau sebesar $0.0 \%$ dan Derajat berat sebanyak 4 atau sebesar $80.0 \%$.

Pada Kelompok tikus yang diberikan Madu $0.27 \mathrm{ml}$, Untuk tikus yang tidak di temukan Steatosis/Vacuolisation sebanyak 1 atau sebesar 20.0\%, Derajat ringan sebanyak 0 atau sebesar $0.0 \%$, Derajat sedang sebanyak 0 atau sebesar $0.0 \%$ dan Derajat berat sebanyak 4 atau sebesar $80.0 \%$.

Pada Kelompok tikus yang diberikan madu $0.54 \mathrm{ml}$, Untuk tikus yang tidak di temukan Steatosis/Vacuolisation sebanyak 0 atau sebesar $0.0 \%$, Derajat ringan sebanyak 0 atau sebesar $0.0 \%$, Derajat sedang sebanyak 1 atau sebesar $20.0 \%$ dan Derajat berat sebanyak 4 atau sebesar $80.0 \%$.

Pada Kelompok kontrol, Untuk tikus yang tidak di temukan Steatosis/Vacuolisation sebanyak 0 atau sebesar $0.0 \%$, Derajat ringan sebanyak 0 atau sebesar $0.0 \%$, Derajat sedang sebanyak 2 atau sebesar $40.0 \%$ dan Derajat berat sebanyak 3 atau sebesar $60.0 \%$.

Untuk analisis data Numerik ini diuji dengan menggunakan uji Kruskal Wallis yaitu Steatosis/Vacuolisation. Hasil uji statistica pada kelompok penelitian diatas diperoleh informasi nilai $\mathrm{P}$ pada variable Steatosis/Vacuolisation lebih besar dari 0.05 (nilai $\mathrm{P}>0.05$ ) yang berarti tidak signifikan atau tidak bermakna secara statistic dengan demikian dapat dijelaskan bahwa tidak terdapat perbedaan rerata yang signifikan secara statistic antara variable Steatosis/Vacuolisation pada kelompok Abrasi Peritoneum, $\mathrm{NaCl} 3 \mathrm{ml}$, Madu 0.27ml, Madu 0.54ml dan Kontrol.

Untuk analisis data ordinal ini diuji dengan menggunakan uji Mann Whitney yaitu Steatosis/Vacuolisation. Hasil uji statistica pada kelompok penelitian diatas diperoleh informasi nilai $\mathrm{P}$ pada variable Steatosis/Vacuolisation lebih besar dari 0.05 (nilai $\mathrm{P}>0.05$ ) yang berarti tidak signifikan atau tidak bermakna secara statistic dengan demikian dapat dijelaskan bahwa tidak terdapat perbedaan rerata yang signifikan secara 
statistic antara variable Steatosis/Vacuolisation pada kelompok Abrasi Peritoneum dan Kontrol, $\mathrm{NaCl} 3 \mathrm{ml}$ dan Kontrol, Madu 0.27ml dan Kontrol, Madu 0.54ml dan Kontrol.

\section{Tabel 2}

\section{Perbandingan antara Steatosis/Vacuolisation}

\begin{tabular}{|c|c|c|c|c|c|c|}
\hline \multirow{2}{*}{ Variabel } & \multirow{2}{*}{$\mathrm{N}$} & \multicolumn{4}{|c|}{ Steatosis/Vacuolisation } & \multirow[b]{2}{*}{$P$} \\
\hline & & Tidak ada & Ringan $<=30 \%$ & Sedang $31-50 \%$ & Berat $>50 \%$ & \\
\hline Abrasi Peritoneum & 5 & $0(0.0 \%)$ & $1(20.0 \%)$ & $0(0.0 \%)$ & $4(80.0 \%)$ & \\
\hline & & & $0(0.0 \%)$ & $0(0.0 \%)$ & $4(80.0 \%)$ & \\
\hline $\mathrm{NaCl} 3 \mathrm{ml}$ & 5 & $1(20.0 \%)$ & & & & \\
\hline Madu $0.27 \mathrm{ml}$ & 5 & $1(20.05)$ & $0(0.0 \%)$ & $0(0.0 \%)$ & $4(80.0 \%)$ & 0.911 \\
\hline Madu $0.54 \mathrm{ml}$ & 5 & $0(0.0 \%)$ & $0(0.0 \%)$ & $1(20.0 \%)$ & $4(80.0 \%)$ & \\
\hline Kontrol & 5 & $0(0.0 \%)$ & $0(0.0 \%)$ & $2(40.0 \%)$ & $3(60.0 \%)$ & \\
\hline
\end{tabular}

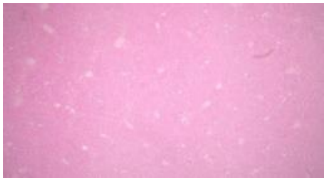

A

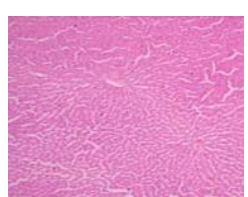

B

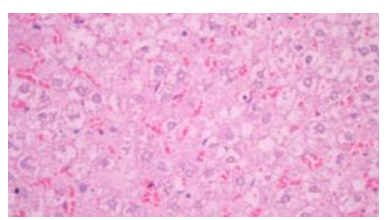

$\mathrm{C}$

Gambar 3

Steatosis 0, 1 Dan 3

\section{Tabel 4}

Perbandingan dua kelompok antara Steatosis/Vacuolisation

\begin{tabular}{|c|c|c|c|c|c|c|}
\hline \multirow[b]{2}{*}{ Variabel } & \multirow[b]{2}{*}{$\mathrm{N}$} & \multicolumn{3}{|c|}{ Steatosis/Vacuolisation } & \multirow[b]{2}{*}{$\begin{array}{c}\text { Derajat Berat } \\
>50 \%\end{array}$} & \multirow[b]{2}{*}{$\begin{array}{l}\text { Nilai } \\
\mathrm{P}\end{array}$} \\
\hline & & $\begin{array}{c}\text { Tidak } \\
\text { ditemukan }\end{array}$ & $\begin{array}{c}\text { Derajat Ringan } \\
<=30 \%\end{array}$ & $\begin{array}{c}\text { Derajat Sedang } \\
31-50 \%\end{array}$ & & \\
\hline $\begin{array}{c}\text { Abrasi } \\
\text { Peritoneum }\end{array}$ & 5 & $0(0.0 \%)$ & $1(20.0 \%)$ & $0(0.0 \%)$ & $4(80.0 \%)$ & 0.841 \\
\hline Kontrol & 5 & $0(0.0 \%)$ & $0(0.0 \%)$ & $2(40.0 \%)$ & $3(60.0 \%)$ & \\
\hline $\mathrm{NaCl} 3 \mathrm{ml}$ & 5 & $1(20.0 \%)$ & $0(0.0 \%)$ & $0(0.0 \%)$ & $4(80.0 \%)$ & 0.841 \\
\hline Kontrol & 5 & $0(0.0 \%)$ & $0(0.0 \%)$ & $2(40.0 \%)$ & $3(60.0 \%)$ & \\
\hline Madu $0.27 \mathrm{ml}$ & 5 & $1(20.05)$ & $0(0.0 \%)$ & $0(0.0 \%)$ & $4(80.0 \%)$ & 0.841 \\
\hline Kontrol & 5 & $0(0.0 \%)$ & $0(0.0 \%)$ & $2(40.0 \%)$ & $3(60.0 \%)$ & \\
\hline Madu $0.54 \mathrm{ml}$ & 5 & $0(0.0 \%)$ & $0(0.0 \%)$ & $1(20.0 \%)$ & $4(80.0 \%)$ & 0.690 \\
\hline Kontrol & 5 & $0(0.0 \%)$ & $0(0.0 \%)$ & $2(40.0 \%)$ & $3(60.0 \%)$ & \\
\hline
\end{tabular}

Arif enre, dkk. Dalam penelitiannya menyatakan bahwa pemberian madu efektif mencegah terjadinya adhesi (Emre et al., 2009). Penelitian ini merupakan penelitian lanjutan dari penelitian sebelumnya, dmana pada penelitian sebelumnya madu Jambi memiliki efektivitas yang baik dibandingkan dengan human albumin dan $\mathrm{NaCl}$ 0.9\% dalam mencegah terjadinya adhesi berdasarkan gambaran makroskopik kejadian adhesi dan skor peritoneal adhesion indeks, terutama pada dosis $0.27 \mathrm{ml} / 200$ gram (Marpaung et al., 2021).

Efek samping berupa hepatoktosisitas merupakan suatu tantangan dalam mencari keamanan dari suatu zat aktif berupa nekrosis sel hepar (Arsad et al., 2014) (Kleiner et 
al., 2014) Pada penelitian ini menunjukkan tidak ditemukan nekrosis sel hepar pada semua kelompok.

Inflamasi merupakan suatu reaksi awal terjadinya kerusakan hepar (Arsad et al., 2014), (Kleiner et al., 2014), (Zhou, Sun, Yang, \& Zhang, 2014) pada penelitian ini perbandingan derajat inflamasi pada pemberian madu baik dengan dosis $0.27 \mathrm{ml}$ maupun pemberian pada dosis $0.54 \mathrm{ml}$ dan kontrol menunjukkan tidak ada perbedaan yang bermakna dengan $\mathrm{p}$ Value 0.69 (> 0.05)

Perdarahan dapat terjadi hepatitis pada kerusakan hepar10 pada penelitian ini kejadian perdarahan menunjukkan tidak terdapat perbedaan baik pada kelompok madu dan control.

Steatosis hepar merupakan lesi fokal yang ditemukan pada drug induced liver injury. Pada penelitian ini ditemukan tidak terdapat perbedaan bermakna nilai steatosis hepar antara tiap kelompok, dimana kelompok madu dosis 0.27/200 g dan kelompok $\mathrm{NaCl}$ 0,9\% terdapat tikus yang tidak menunjukkan gejala tersebut (Kleiner, 2017).

\section{Kesimpulan}

Gambaran mikroskopis hati tikus wistar berupa steatosis hepar setelah pemberian antiadhesif intraabdominal berupa madu jambi menunjukkan tidak ada perbedaan bermakna. Oleh sebab itu, pemberian madu jambi sebagai anti adhesive dianggap aman. 


\section{BIBLIOGRAFI}

Arsad, S. S., Esa, N. M., \& Hamzah, H. (2014). Histopathologic changes in liver and kidney tissues from male Sprague Dawley rats treated with Rhaphidophora decursiva (Roxb.) Schott extract. J Cytol Histol S, 4(1), 1-6. Google Scholar

Coccolini, Federico, Ansaloni, Luca, Manfredi, Roberto, Campanati, Luca, Poiasina, Elia, Bertoli, Paolo, Capponi, Michela Giulii, Sartelli, Massimo, Saverio, Salomone Di, \& Cucchi, Michele. (2013). Peritoneal adhesion index (PAI): proposal of a score for the "ignored iceberg" of medicine and surgery. World Journal of Emergency Surgery, 8(1), 1-5. Google Scholar

Emre, Arif, Akin, Murat, Isikgonul, Ipek, Yuksel, Osman, Anadol, Ahmet Ziya, \& Cifter, Cagatay. (2009). Comparison of intraperitoneal honey and sodium hyaluronate-carboxymethylcellulose (SeprafilmTM) for the prevention of postoperative intra-abdominal adhesions. Clinics, 64, 363-368. Google Scholar

Giusto, Gessica, Vercelli, Cristina, Iussich, Selina, Audisio, Andrea, Morello, Emanuela, Odore, Rosangela, \& Gandini, Marco. (2016). A pectin-honey hydrogel prevents postoperative intraperitoneal adhesions in a rat model. BMC Veterinary Research, 13(1), 1-5. Google Scholar

Kleiner, David E. (2017). Drug-induced liver injury: the hepatic pathologist's approach. Gastroenterology Clinics, 46(2), 273-296. Google Scholar

Kleiner, David E., Chalasani, Naga P., Lee, William M., Fontana, Robert J., Bonkovsky, Herbert L., Watkins, Paul B., Hayashi, Paul H., Davern, Timothy J., Navarro, Victor, \& Reddy, Rajender. (2014). Hepatic histological findings in suspected drug-induced liver injury: systematic evaluation and clinical associations. Hepatology, 59(2), 661-670. Google Scholar

Marpaung, Willy Hardy, Purwakhanti, Anati, Ayudya, Esa Indah, \& Reza, Ade Tan. (2021). Efektivitas Madu Jambi, Human Albumin, Normal Saline Sebagai Zat Anti Adhesive Intraabdominal pada Luka Bersih Tidak Terkontaminasi pada Gambaran Makroskopik. Jurnal of Admiration, 2(2), 292-299. Google Scholar

Negahi, Ali Reza, Hosseinpour, Parisa, Vaziri, Mohammad, Vaseghi, Hamed, Darvish, Pedram, Bouzari, Behnaz, \& Mousavie, Seyed Hamzeh. (2019). Comparison of Honey versus Polylactide Anti-Adhesion Barrier on Peritoneal Adhesion and Healing of Colon Anastomosis in Rabbits. Open Access Macedonian Journal of Medical Sciences, 7(10), 1597. Google Scholar

Saber, Aly, Shekidef, Mohammed H., \& Saber, Aya Aly. (2015). Effect of Honey versus Icodextrin on Adhesion Reformation after Adhesiolysis: an Experimental Study in Rats. Journal of Surgery, 4(1-1), 5-10. Google Scholar

Vallianou, Natalia G., Gounari, Penny, Skourtis, Alexandros, Panagos, John, \& Kazazis, Christos. (2014). Honey and its anti-inflammatory, anti-bacterial and anti-oxidant 
Comparison of Safety Intraabdominal Antiadhesive Agent Base on Hepatetic Steatosis in Wistar RAT

properties. Gen Med (Los Angel), 2(132), 1-5. Google Scholar

Zhou, Jianhong, Sun, Qi, Yang, Zhirong, \& Zhang, Jie. (2014). The hepatotoxicity and testicular toxicity induced by arecoline in mice and protective effects of vitamins C and E. The Korean Journal of Physiology \& Pharmacology, 18(2), 143-148. Google Scholar

\section{Copyright holder:}

Miftahurrahmah, Budi Justicia, Willy Hardy Marpaung (2022)

First publication right:

Syntax Literate: Jurnal Ilmiah Indonesia

This article is licensed under:

(c) (i) (?) 